University of New Hampshire

University of New Hampshire Scholars' Repository

Faculty Publications

2-9-2021

\title{
The Worst Is Behind Us: News Media Choice and False Optimism in the Summer of 2020
}

Lawrence C. Hamilton

University of New Hampshire, lawrence.hamilton@unh.edu

Thomas G. Safford

University of New Hampshire, tom.safford@unh.edu

Follow this and additional works at: https://scholars.unh.edu/faculty_pubs

Comments

An earlier version of this article was published in Academia Letters, available online.

\section{Recommended Citation}

Hamilton, Lawrence C. and Safford, Thomas G., "The Worst Is Behind Us: News Media Choice and False Optimism in the Summer of 2020" (2021). Faculty Publications. 1001.

https://scholars.unh.edu/faculty_pubs/1001

This Article is brought to you for free and open access by University of New Hampshire Scholars' Repository. It has been accepted for inclusion in Faculty Publications by an authorized administrator of University of New Hampshire Scholars' Repository. For more information, please contact Scholarly.Communication@unh.edu. 
August 8, 2021

\title{
The Worst Is Behind Us: \\ News Media Choice and False Optimism in the Summer of 2020
}

Lawrence C. Hamilton

Department of Sociology

University of New Hampshire

ORCID: 0000-0003-1977-0649

Lawrence.Hamilton@unh.edu
Thomas G. Safford

Department of Sociology

University of New Hampshire

ORCID: 0000-0003-1171-4634

Tom.Safford@unh.edu

Paper presented at annual meeting of the American Sociological Association, August 8 2021. An earlier version appeared in Academia Letters (2021), article 232.

\begin{abstract}
In the summer of 2020, mitigation efforts slowed the first US wave of the COVID-19 pandemic. Experts warned, however, that without coordinated, sustained mitigation-such as testing and tracing, limited travel or gatherings, social distancing and mask wearing - the worst could lie ahead. A July survey found majority (59\%) agreement with the expert warnings, while a minority (27\%) mistakenly thought that the worst was behind us, or that COVID-19 was not a real problem. Among frequent Fox News and conservative talk radio consumers, however, large majorities (67-80\%) held such false optimism or denial views, in contrast with small minorities (9-16\%) among public radio and local television audiences. The impacts of news media choice were strongest among Republicans. Republicans who frequently watched Fox News were significantly more likely to express false optimism/denial views, whereas Republicans who watched a local TV station (ABC affiliate) or listened to public radio were significantly less likely to express false optimism/denial. News media choices had weaker effects on political Independents, however, and almost no effects on Democrats. These news media $\times$ party interactions suggest political asymmetry in the importance of "elite cues" for shaping COVID-19 perceptions. Unrealistic perceptions had real consequences: false optimism and denial correlate with lower support for mitigation steps, which worsened the pandemic.
\end{abstract}

\section{Introduction}

The first US case of COVID-19 was confirmed in January 2020; by late March the rate of infection reached tens of thousands per day. Infections peaked above 30,000 cases and 2,000 deaths per day in April, before mitigation efforts including stay-at-home policies slowed down this first wave. By late July, during the survey described in this paper, there had been 160,000 confirmed deaths nationwide. The rate of new fatalities remained below its spring peak, but infections were rising again. Epidemiologists warned that without mitigation on a much larger scale, there was nothing to prevent worse outcomes in the seasons ahead. Coordinated mitigation efforts did not happen, and the warnings came true. In winter 2020/2021, daily hospitalizations 
and deaths far exceeded their spring 2020 peak (Figure 1), and more than half a million Americans had died.

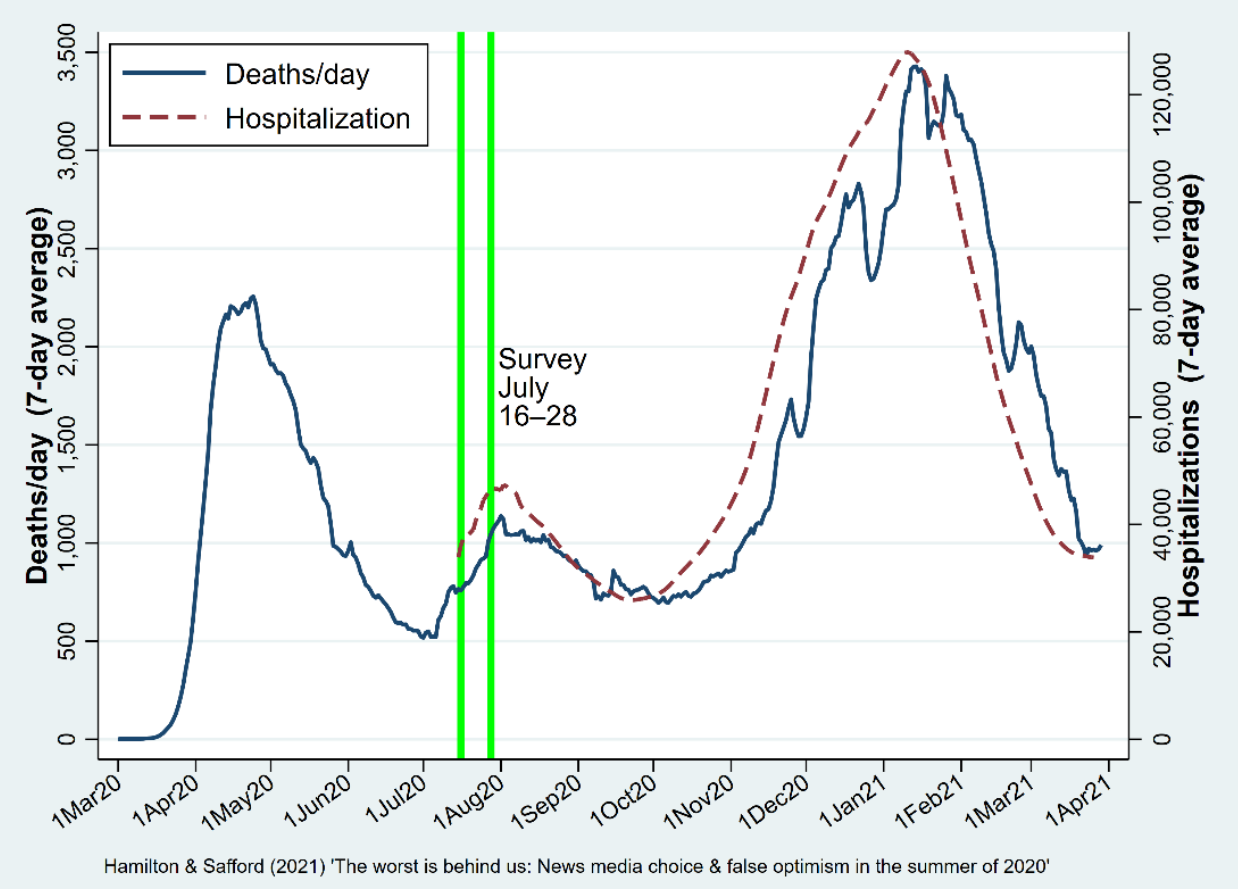

Figure 1: Daily U.S. COVID-19 deaths and hospitalization (7-day averages) from March 12020 to March 29 2021. Vertical lines enclose dates of our July 2020 survey. COVID data: Roser et al. (2020).

Our survey took place from July 16 to 28, in the US state of New Hampshire. During this period, the state was experiencing comparatively mild impacts, averaging around 30 new cases and one death per day. As elsewhere, things subsequently worsened: in January the 7-day averages passed 700 new cases and 10 deaths per day. One question on the July survey had invited respondents to look forward: Did they think that for the US, the worst of the pandemic was yet to come? Or that the worst was behind us, or even that COVID-19 was not really a major problem? In hindsight, as in scientifically-informed opinion at the time, the latter two views reflect false optimism at best, or simply denial. They contributed to the disaster by implying less need for prevention, whether policy or individual behavior.

What were the social bases of false optimism? Aside from its demographic patterns, what can we say about the role of information sources in supporting (or countering) inaccurate perceptions that the pandemic was waning or unreal, so preventive steps were not urgent? The July survey sheds light on these questions.

\section{Data and Methods}

Our summer 2020 survey was part of a series examining coronavirus-related beliefs and behavior (Hamilton \& Safford 2020b, 2020c, 2021; Safford \& Hamilton 2020). Background and citations to related studies appear in previous articles on public trust in scientists regarding vaccines (Hamilton et al. 2015), the Zika virus pandemic (Hamilton \& Safford 2020a; Safford et al. 2017), 
and topics such as climate change (Hamilton 2015; Safford et al. 2020). Other studies give evidence that on science-related issues, New Hampshire surveys approximate US nationwide responses (e.g., Hamilton et al. 2019).

Sampling for this online survey employed the University of New Hampshire Survey Center's Granite State Panel, composed of residents recruited randomly from phone numbers across the state. A total of 959 people responded to the July 2020 survey. Weights adjusting for representativeness in terms of age, gender, education, political party and region have been applied to all analyses in this article.

Variables analyzed here are listed in Table 1, with response summaries and codes for regression. Independent variables include age, gender, education and political party, along with how frequently respondents watched or listened to four news sources: Fox News, conservative talk radio, a local TV station (WMUR, an ABC affiliate), or New Hampshire public radio (NHPR).

Figure 2 charts responses to our dependent variable, the behind us question. Although 59\% agreed with expert warnings that the worst of the pandemic was yet to come, $21 \%$ took a more sanguine view that the worst was behind us, while 6\% maintained that COVID-19 had not been a real problem. The latter two views proved badly mistaken. Combing the two responses defines a $\{0,1\}$ indicator of false optimism or denial $(27 \%)$.

Table 1: Variables in this analysis, with weighted response summaries and codes used for regression.

\section{Independent Variables}

Age - 19 to 91 years, mean 49

Gender - male (0,48\%), female (1,52\%)

Education - high school or less (1,34\%), technical school/some college (2, 33\%), college graduate $(3,21 \%)$, postgraduate $(4,12 \%)$

Party - Democrat (48\%), Independent (10\%), Republican (42\%) each coded as a 0/1 dummy variable

Fox News - watch never/DK (0,58\%), occasionally (1, 24\%), frequently $(2,18 \%)$

Conservative talk radio - listen never/DK (0,74\%), occasionally (1, 17\%), frequently $(2,9 \%)$

Local TV (WMUR, an ABC affiliate) - watch never/DK (0, 21\%), occasionally (1, 38\%),

frequently $(2,41 \%)$

Public radio (NHPR) - listen never/DK (0, 45\%), occasionally (1, 33\%), frequently $(2,22 \%)$

\section{Dependent Variable}

Behind us - Which statement do you think is more accurate concerning the coronavirus of COVID-19 in the United States?

- The worst is yet to come $(0,59 \%)$

- The worst is behind us $(1,21 \%)$

- COVID-19 has not really been a major problem in the US $(1,6 \%)$

- Don't know/no answer (0, 14\%) 


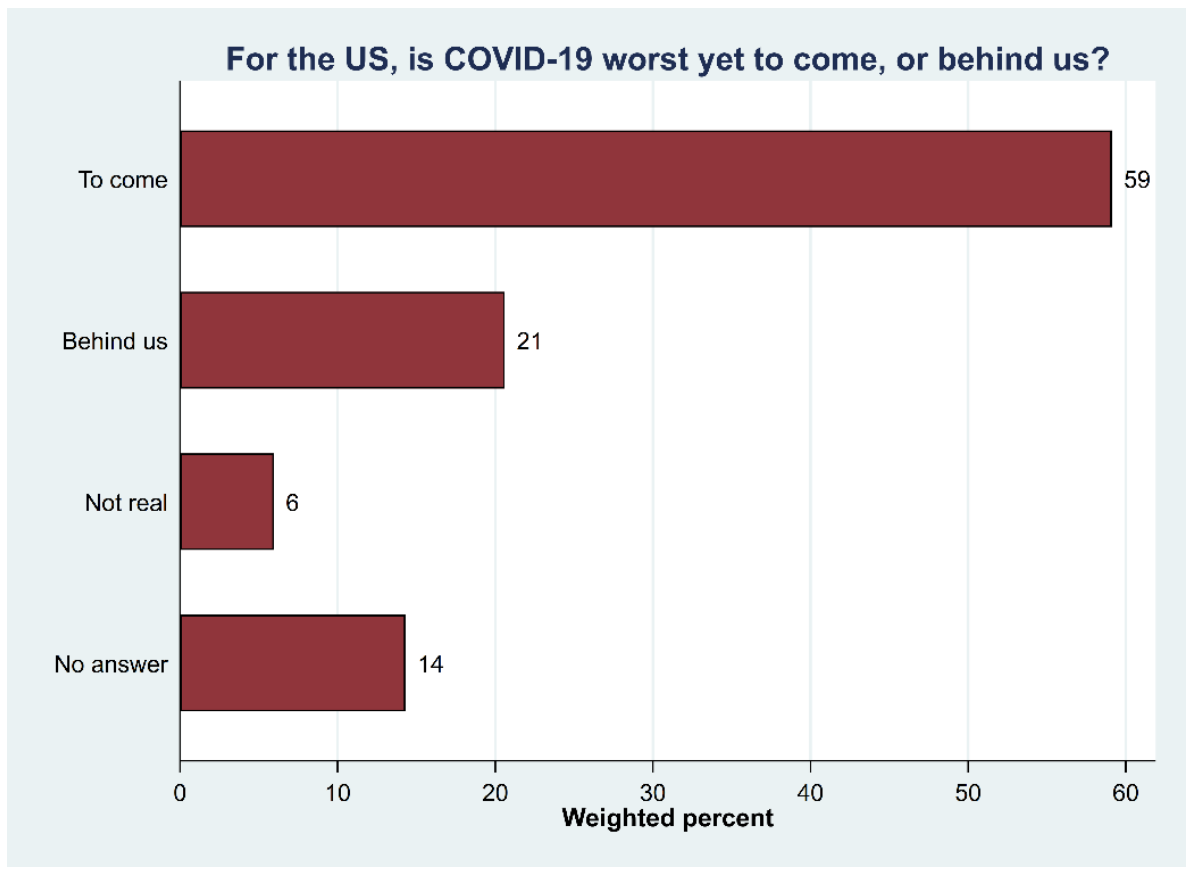

Figure 2: Which statement do you think is more accurate concerning COVID-19 in the United States?

\section{Results}

Figure 3 breaks down the percentage of false-optimism responses (behind $u s=1$ ) by respondent characteristics and media choices. Differences between age groups, men and women, or by education appear small compared with the 50-point gap separating Republicans (54\% false optimism) from Democrats (4\% false optimism). Independents (22\%) stand closer to Democrats. Even wider gaps separate those who frequently $(67 \%)$ or never $(10 \%)$ watch Fox News, and frequently $(80 \%)$ or never $(13 \%)$ listen to conservative talk radio. Significant differences occur in the opposite direction among local TV watchers and public radio listeners. These news-media effects reflect information conveyed by each source — often downplaying the seriousness of the pandemic (in line with President Trump's pronouncements) on Fox News and conservative talk radio, contrasting with more attention to infectious-disease expert perspectives on local TV and public radio. Recent studies explore the resulting impacts of conservative media on coronavirus conspiracy beliefs (Jamieson \& Albarracin 2020), preventive behavior (Simonov et al. 2020) and COVID-19 infections (Bursztyn et al. 2020). 


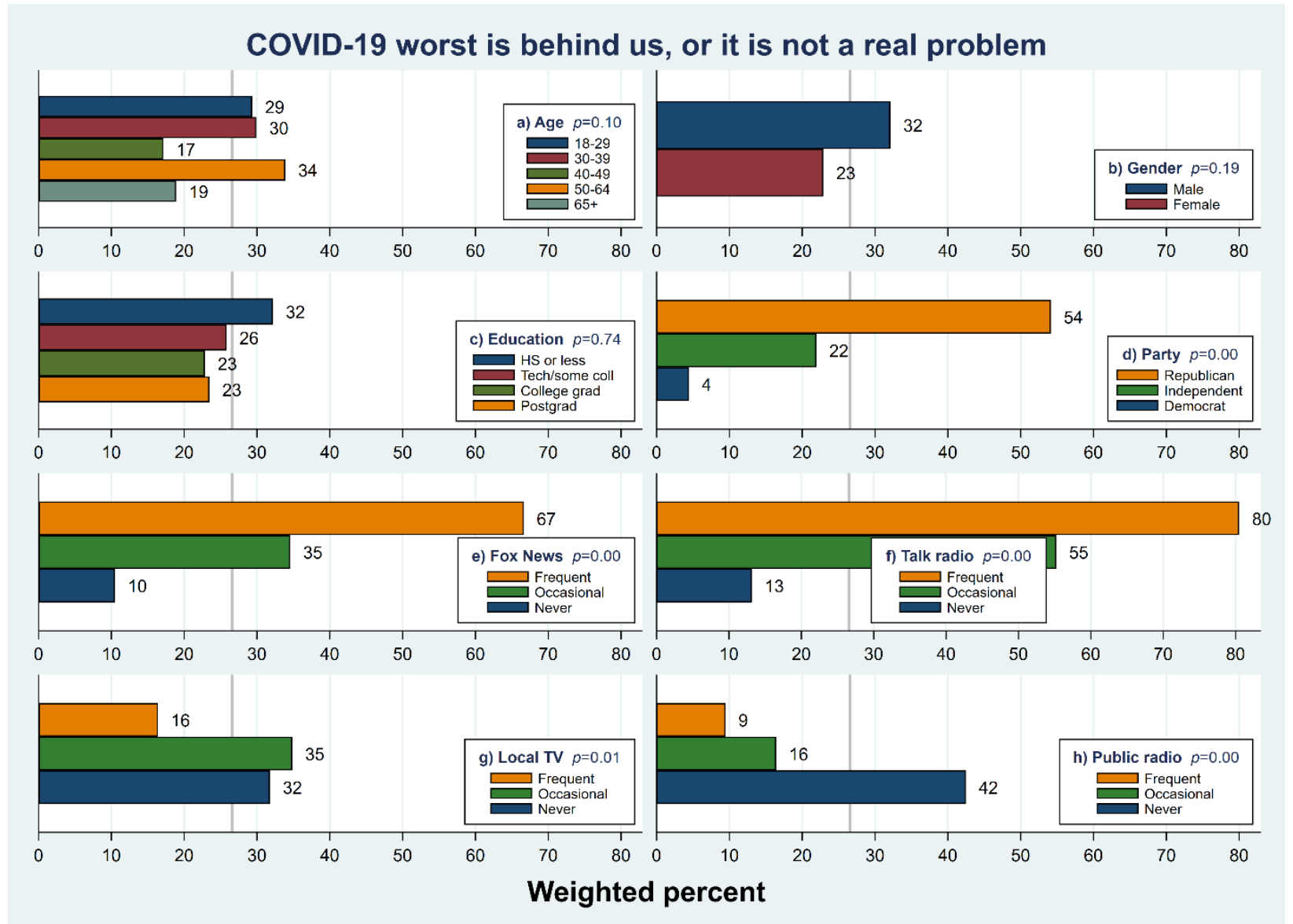

Figure 3: Percentages saying the worst is behind us or COVID-19 is not really a major problem (overall, 27\%) by respondent characteristics and news media choices. Probabilities from designbased $F$ tests.

Political identity is known to influence news media choices (e.g., Bolin \& Hamilton 2018), so relationships in Figures $3 \mathrm{e}-\mathrm{h}$ might be spurious. Media/party associations also raise the question of whether media effects might be different across parties. A multivariate analysis summarized in Table 2 tests these possibilities by entering all four media items, together with media $\times$ party interactions, age, gender and education, into a logit regression model predicting the odds of a false optimism/denial response (behind $u s=1$ ). Older respondents are less inclined to false optimism/denial $(p=0.028)$, but otherwise Republican identity and media $\times$ Republican interactions dominate these results. The significant main effect for Republican $(p<0.0005)$ indicates that, even among respondents who say they never watch or listen to any of the four listed news sources, Republicans are more inclined toward false optimism/denial. Nonsignificant main effects for each of the four media items mean that news media choices had little effect on perceptions among Democrats, the base or reference category of party.

Turning to interactions, the positive Fox News $\times$ Republican coefficient $(p=0.010)$ tells us that among Republicans, more frequent Fox viewership is associated with higher probabilities of false optimism/denial, as visualized in Figure 4a. Conversely, the negative local TV $\times$ Republican $(p=0.012)$ and public radio $\times$ Republican $(p=0.008)$ coefficients indicate that Republicans who attended to those news sources were less inclined toward false optimism/denial 
(Figures 4c and 4d). News media choices show no significant effects among Democrats or Independents.

Table 2: Weighted logit regression of response that worst is behind us or COVID-19 is not a real problem (behind us $=1$ ) on respondent age, gender, education, political party and frequency of news media consumption, with news $\times$ party interactions. Showing coefficients, linearized standard errors, $t$-test probabilities, and $95 \%$ confidence intervals. Colors denote statistically significant positive (blue, more false optimism) or negative (red, less false optimism) effects; estimation sample $n=899$.

\begin{tabular}{|c|c|c|c|c|c|}
\hline Predictor & Coefficient & SE & $p$ & ci lower & ci upper \\
\hline Age (years) & -0.025 & 0.011 & 0.028 & -0.048 & -0.003 \\
\hline Gender (F) & 0.050 & 0.363 & 0.890 & -0.662 & 0.762 \\
\hline Education & 0.246 & 0.188 & 0.192 & -0.124 & 0.615 \\
\hline \multicolumn{6}{|l|}{ Party } \\
\hline Democrat (base) & $\ldots$. & $\ldots$. & $\ldots$. & $\ldots$. & $\ldots$. \\
\hline Independent & 2.386 & 1.226 & 0.052 & -0.019 & 4.792 \\
\hline Republican & 4.408 & 0.851 & 0.000 & 2.739 & 6.078 \\
\hline Fox News & -0.264 & 0.506 & 0.602 & -1.257 & 0.729 \\
\hline \multicolumn{6}{|l|}{ Fox News $\times$ party } \\
\hline Democrat (base) & $\ldots$. & $\ldots$. & $\ldots$. & $\ldots$ & $\ldots$. \\
\hline Independent & -0.069 & 0.866 & 0.936 & -1.769 & 1.631 \\
\hline Republican & 1.453 & 0.564 & 0.010 & 0.346 & 2.561 \\
\hline Talk radio & 0.879 & 0.725 & 0.226 & -0.544 & 2.303 \\
\hline \multicolumn{6}{|l|}{ Talk radio $\times$ party } \\
\hline Democrat (base) & $\ldots$. & $\ldots$ & $\ldots$. & $\ldots$ & $\ldots$ \\
\hline Independent & -0.633 & 1.154 & 0.583 & -2.898 & 1.631 \\
\hline Republican & -0.104 & 0.785 & 0.894 & -1.646 & 1.437 \\
\hline Local TV & 0.731 & 0.447 & 0.102 & -0.146 & 1.608 \\
\hline \multicolumn{6}{|l|}{ Local TV $\times$ party } \\
\hline Democrat (base) & $\ldots$. & $\ldots$. & $\ldots$. & $\ldots$. & $\ldots$. \\
\hline Independent & -0.397 & 0.805 & 0.622 & -1.977 & 1.183 \\
\hline Republican & -1.591 & 0.633 & 0.012 & -2.833 & -0.349 \\
\hline Public radio & 0.374 & 0.389 & 0.337 & -0.390 & 1.139 \\
\hline \multicolumn{6}{|l|}{ Public radio $\times$ party } \\
\hline Democrat (base) & $\ldots$. & $\ldots$. & $\ldots$. & $\ldots$ & $\ldots$. \\
\hline Independent & 0.394 & 0.617 & 0.523 & -0.818 & 1.606 \\
\hline Republican & -1.443 & 0.540 & 0.008 & -2.502 & -0.384 \\
\hline Constant & -3.966 & 0.774 & 0.000 & -5.485 & -2.447 \\
\hline
\end{tabular}

${ }^{*} p<0.05 \quad{ }^{* *} p<0.01 \quad{ }^{* * *} p<0.001 \quad$ (two-tailed $t$ tests)


(a) Fox News $\times$ party interaction

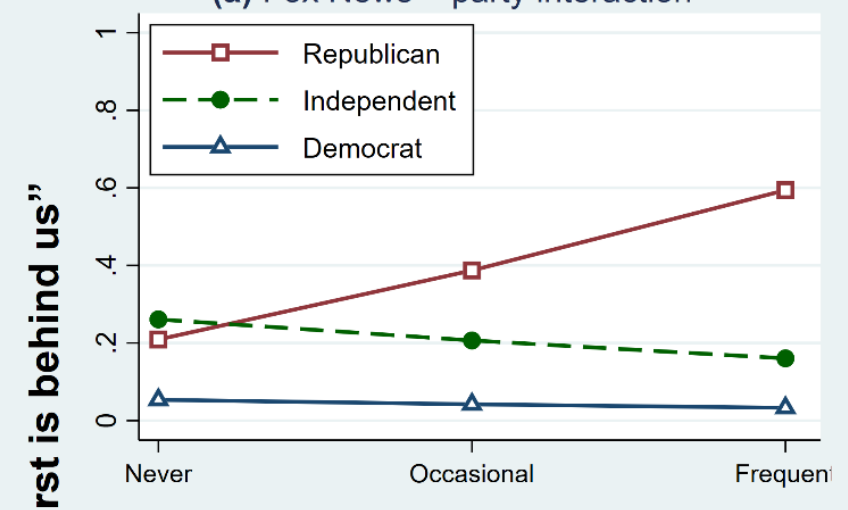

(c) Local TV news $\times$ party interaction

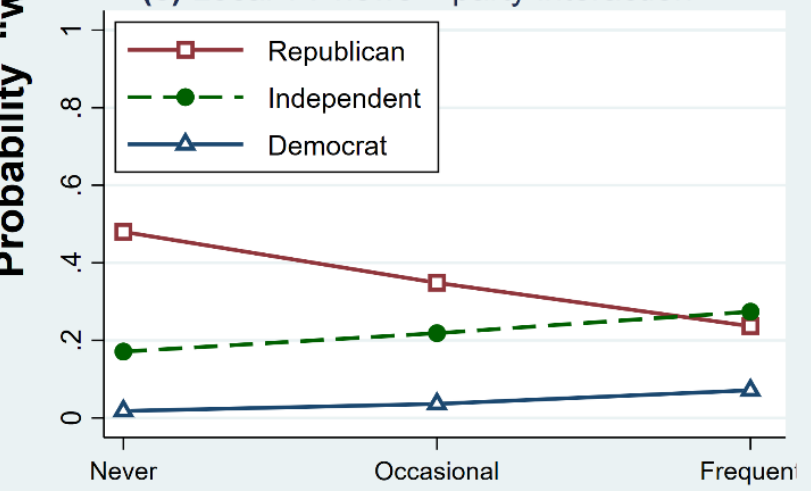

(b) Conservative talk radio $\times$ party interaction

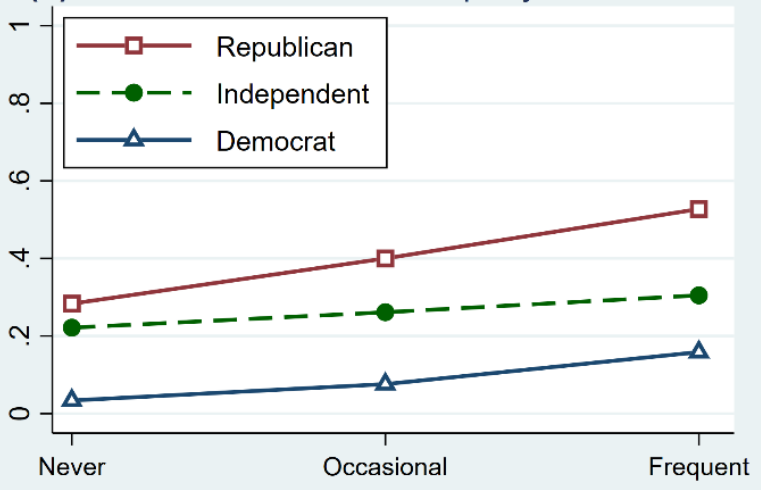

(d) Public radio $\times$ party interaction

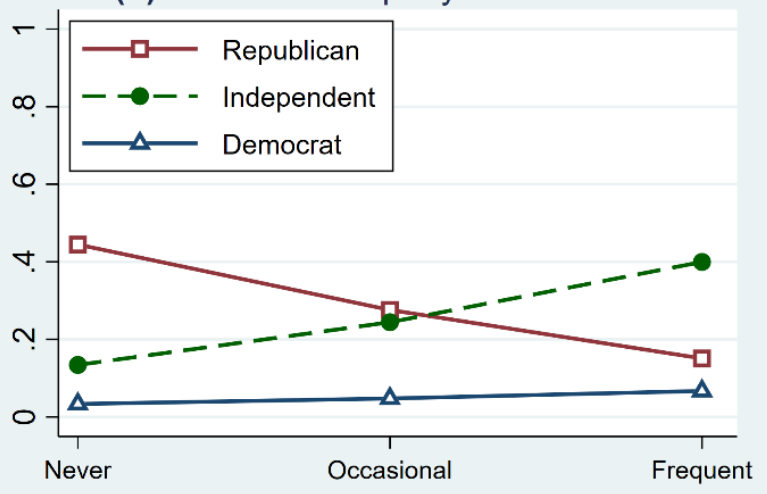

Hamilton \& Safford (2021) 'The worst is behind us: News media choice and false optimism in the summer of 2020'

Figure 4: Visualizing news media $\times$ party interaction effects: adjusted margins plots based on regression model of Table 2.

\section{Discussion}

Associations between partisan identity, news media preferences and perceptions are well known for many topics, including climate change as well as COVID-19. Our analysis of 2020 survey data adds a new element: evidence that media choices affected Republican COVID-19 perceptions more than they did for other political groups. Elite cues from co-partisan political or media leaders tend to disproportionately influence conservatives (Bullock 2011; Carmichael et al. 2017; Hamilton \& Safford 2021). In this new COVID-19 analysis, it appears that elite cues from sources that are not co-partisan may disproportionately affect conservatives as well. For Republicans in particular, attending to local TV news and public radio supported realism; attending to Fox News and conservative talk radio did the opposite, implying less need for prevention.

Our survey's behind us indicator has tetrachoric correlations of -0.72 with mask wearing, -0.67 with concern that the respondent or their family might become sick, and -0.85 with prioritizing government efforts to control the virus. Through such connections to behavioral and policy mitigation steps, false optimism and denial contributed to worsening the pandemic. 


\section{Acknowledgments}

Support for coronavirus questions on Granite State Panel surveys was provided by the Carsey School of Public Policy and the College of Liberal Arts at the University of New Hampshire. The Granite State Panel is conducted by the UNH Survey Center. Any opinions, findings, and conclusions or recommendations expressed in this paper are those of the authors and do not necessarily reflect the views of supporting organizations.

\section{References}

Bolin, J.L. \& L.C. Hamilton. 2018. "The news you choose: News media preferences amplify views on climate change." Environmental Politics 27(3):455-476.

https://doi.org/10.1080/09644016.2018.1423909

Bullock, J.G. 2011. "Elite influence on public opinion in an informed electorate." American Political Science Review 105:496-515. https://doi.org/10.1017/S0003055411000165

Bursztyn, L., A. Rao, C. Roth \& D. Yanagizawa-Drott. 2020. "Misinformation during a pandemic." Working Paper 27417, National Bureau of Economic Research.

https://www.nber.org/papers/w27417

Carmichael, J.T., R.J. Brulle \& J.K. Huxster. 2017. "The Great Divide: Understanding the role of media and other drivers of the partisan divide in public concern over climate change in the USA, 2001-2014." Climatic Change 141:599-612. https://doi.org/10.1007/s10584-017$\underline{1908-1}$

Hamilton, L.C. 2015. "Conservative and liberal views of science: Does trust depend on topic?" Durham, NH: Carsey School of Public Policy. http://scholars.unh.edu/carsey/252/

Hamilton, L.C. \& T.G. Safford. 2020a. "Ideology affects trust in science agencies during a pandemic.” Durham, NH: Carsey School of Public Policy. http://scholars.unh.edu/carsey/391

Hamilton, L.C. \& T.G. Safford. 2020b. "Trusting scientists more than the government: New Hampshire perceptions of the pandemic." Durham, NH: Carsey School of Public Policy. http://scholars.unh.edu/carsey/401

Hamilton, L.C. \& T.G. Safford. 2020c. "Conservative media consumers less likely to wear masks and less worried about COVID-19.” Durham, NH: Carsey School of Public Policy. https://scholars.unh.edu/carsey/415

Hamilton, L.C. \& T.G. Safford. 2021. "Elite cues and the rapid decline of trust in scientists on COVID-19.” Sociological Perspectives. https://doi.org/10.1177/07311214211022391

Hamilton, L.C., J. Hartter \& K. Saito. 2015. "Trust in scientists on climate change and vaccines." Sage Open https://doi.org/10.1177/2158244015602752 
Hamilton, L.C., J. Hartter \& E. Bell. 2019. "Generation gaps in U.S. public opinion on renewable energy and climate change.” PLoS One https://doi.org/10.1371/journal.pone.0217608

Jamieson, K.H. \& D. Albarracin. 2020. "The relation between media consumption and misinformation at the outset of the SARS-CoV-2 pandemic in the US." Harvard Kennedy School Misinformation Review, Special Issue on Covid and Misinformation. https://doi.org/10.37016/mr-2020-012

Roser, M., H. Ritchie, E. Ortiz-Ospina \& J. Hasell. 2020. "Coronavirus Pandemic (COVID-19)." Published online at OurWorldInData.org. https://ourworldindata.org/coronavirus accessed $3 / 30 / 2020$.

Safford, T.G. \& L.C. Hamilton. 2020. "Views of a fast-moving pandemic: A survey of Granite Staters' responses to COVID-19.” Durham, NH: Carsey School of Public Policy. http://scholars.unh.edu/carsey/396

Safford, T.G., L.C. Hamilton \& E.H. Whitmore. 2017. "The Zika virus threat: How concerns about scientists may undermine efforts to combat the pandemic." Durham, NH: Carsey School of Public Policy. http://scholars.unh.edu/carsey/299/

Safford, T.G., E.H. Whitmore \& L.C. Hamilton. 2020. "Questioning scientific practice: Linking beliefs about scientists, science agencies, and climate change.” Environmental Sociology 6(2):194-206. https://doi.org/10.1080/23251042.2019.1696008

Simonov, A., S.K. Sacher, J.-P.H. Dubé \& S. Biswas. 2020. "The persuasive effect of Fox News: Non-compliance with social distancing during the COVID-19 pandemic." Working Paper 27237, National Bureau of Economic Research. http://www.nber.org/papers/w27237 